\title{
Spring bloom in the central Strait of Georgia: interactions of river discharge, winds and grazing
}

\author{
Kedong Yin ${ }^{1, *}$, Paul J. Harrison ${ }^{1}$, Robert H. Goldblatt ${ }^{1}$, Richard J. Beamish ${ }^{2}$ \\ ${ }^{1}$ Department of Oceanography, University of British Columbia, Vancouver, British Columbia, Canada V6T 124 \\ ${ }^{2}$ Pacific Biological Station, Department of Fisheries and Oceans, Nanaimo, British Columbia, Canada V9R $5 \mathrm{~K} 6$
}

\begin{abstract}
A 3 wk cruise was conducted to investigate how the dynamics of nutrients and plankton biomass and production are coupled with the Fraser River discharge and a wind event in the Strait of Georgia estuary (B.C., Canada). The spring bloom was underway in late March and early April, 1991, in the Strait of Georgia estuary. The magnitude of the bloom was greater near the river mouth, indicating an earlier onset of the spring bloom there. A week-long wind event (wind speed $>4 \mathrm{~m} \mathrm{~s}^{-1}$ ) occurred during April 3-10. The spring bloom was interrupted, with phytoplankton biomass and production being reduced and $\mathrm{NO}_{3}$ in the surface mixing layer increasing at the end of the wind event. Five days after the wind event (on April 15), $\mathrm{NO}_{3}$ concentrations were lower than they had been at the end of the wind event, indicating a utilization of $\mathrm{NO}_{3}$ during April 10-14. However, the utilized $\mathrm{NO}_{3}$ did not show up in phytoplankton biomass and production, which were lower than they had been at the end (April 9) of the wind event. During the next $4 \mathrm{~d}$, April 15-18, phytoplankton biomass and production gradually increased, and $\mathrm{NO}_{3}$ concentrations in the water column decreased slowly, indicating a slow recovery of the spring bloom. Zooplankton data indicated that grazing pressure had prevented rapid accumulation of phytoplankton biomass and rapid utilization of $\mathrm{NO}_{3}$ after the wind event and during these $4 \mathrm{~d}$. As a result, $\mathrm{NH}_{4}$ was generated at a rate faster than it was utilized by phytoplankton and hence, its concentrations remained at higher levels during April 15-18 than during the wind event. Also, total nitrogen in the water column decreased after the wind event. This study presents the first set of data on daily scales to demonstrate how biological variables are coupled with physical variables in vertical profiles in the Strait of Georgia estuary and to reveal how a wind event affected the spring bloom and consequently the phasing between phytoplankton and zooplankton in the region.
\end{abstract}

KEY WORDS: Spring bloom - River discharge - Nutrients Winds Phytoplankton biomass Primary productivity $\cdot$ Zooplankton $\cdot$ Estuary $\cdot$ Strait of Georgia

\section{INTRODUCTION}

The Fraser River discharge plays a key role as a physical driving force in the water circulation and biological productivity in the Strait of Georgia (Harrison et al. 1983, LeBlond 1983), which lies between Vancouver Island and the lower mainland of British Columbia, Canada. Previous work by Parsons et al. (1969, 1970) and Stockner et al. (1979), which mainly focused on the seasonal change in nutrients and plankton production in the Strait (including some inlets), showed that phytoplankton production started to increase slowly in early March and the spring bloom

•E-mail: kedong@unixg.ubc.ca occurred in April during the beginning of the Fraser River freshet. Data on short time scale (daily) variations in nutrients and phytoplankton biomass are still lacking for the Strait of Georgia and Fraser River plume region.

The spring bloom is an essential link between physical forcing and zooplankton (Mann 1993). Zooplankton peak abundance usually lags behind a phytoplankton bloom because the increased food supply induces egg laying and the production of young stages takes place weeks later (Frost 1980). Therefore, zooplankton abundance in spring is usually dependent on phytoplankton production. However, the phasing between the spring bloom and zooplankton in the Strait of Georgia is rather different. In the Strait, the copepod Neocalanus 
plumchrus is the dominant zooplankter ( $>50 \%$ of total zooplankton biomass) during the spring bloom period (Fulton 1973, Harrison et al. 1983). This species matures and breeds in deep water during winter and the young stages migrate to the surface during March and April (Fulton 1973) This migration is ontogenetic and independent of the spring bloom (Harrison et al. 1983). However, the survival and growth of the young stages of $N$ plumchrus will rely on how much phytoplankton biomass or how fast phytoplankton production is available when they reach the euphotic zone. Thus, the matching or phasing between zooplankton and phytoplankton depends mainly on the timing of the spring bloom alone, assuming the timing of zooplankton ontogenetic migration to the surface waters is relatively constant each year

Freshwater outflow increases stratification of the water column. However, wind mixing reduces the degree of stratitication, causing nutrients and phytoplankton biomass to be redistributed in the water column. A wind event in spring can interrupt the development of the spring bloom because phytoplankton are mixed to deeper waters and are lost upon restratification. Strong winds in spring were used to explain a delayed spring bloom in Puget Sound (Winter et al. 1975). This is probably one reason why phytoplankton biomass often increases in steps as a succession of peaks and troughs due to physical events (Erga \& Heimdal 1984, Sournia et al. 1987).

The objectives of this study were to investigate the temporal (day-to-day) and mesoscale spatial variations in the distribution of salinity, temperature, fluores- cence and nutrients in spring. During the cruise, a wind event occurred, thus we also report how the wind event interrupted the spring bloom and how grazing by copepods affected the duration and magnitude of the spring bloom

\section{MATERIALS AND METHODS}

The cruise was conducted during April 2-19, 1991 , along a transect (Fig. 1) in the Strait of Georgia covering a region from the riverine plume station (Stn S2) to an area not influenced by recent river discharge ( $\mathrm{Stn} \mathrm{S} 1$ ). The distance between Stns S2 and S1 is about $108 \mathrm{~km}$. The water depth at these stations ranged from $100 \mathrm{~m}$ to $200 \mathrm{~m}$.

Sampling and data processing. At each station, a continuous vertical profile (0 to $25 \mathrm{~m}$ ) of temperature, salinity, in vivo fluorescence and nutrients (nitrate+ nitrite, ammonium, phosphate and silicate) was obtained. The details of the vertical profiling system are described in Jones et al. (1991).

Incident solar irradiance (PAR) was continuously monitored with a Li-Cor (model Li-185) light meter equipped with a Lambda Instruments 190 S Surface Quantum Sensor. Total daily irradiance (05:30 to 22:00 h Pacific Daylight Time) was calculated by integrating the area under the light curve (400-700 $\mathrm{nm}$ ) and used for calculating daily primary production.

Subsurface irradiance was measured with a Li-Cor (Li-185B) light meter equipped with a Lambda Instruments 192S Underwater Quantum Sensor. On the basis

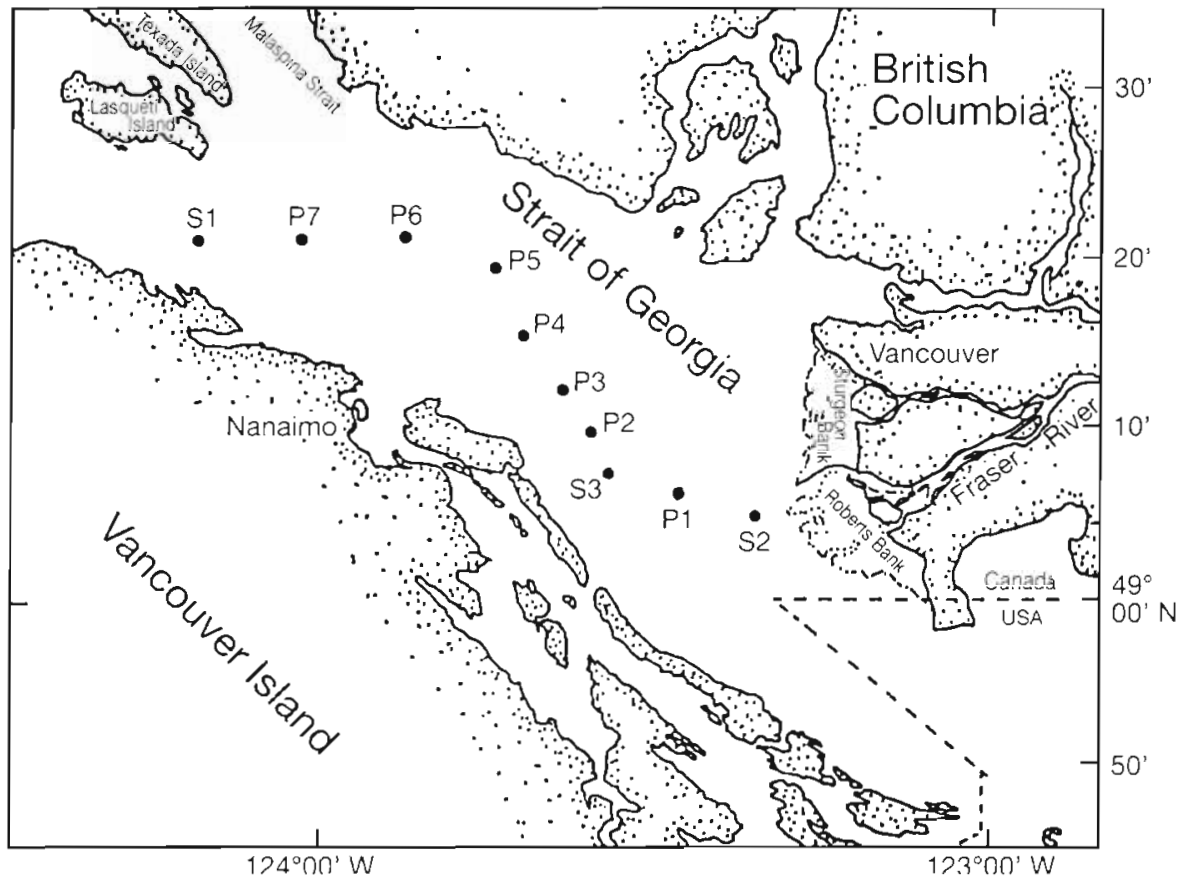

Fig. 1 Stations in the study area in the Strait of Georgla for the cruise conducted during April 2-19, 1991 S: stations occupied for $24 h_{i} P$ : transect stations 
of light penetration (usually $100,55,30,10,3$ and $1 \%$ of surface irradiance), water samples were collected from the 6 corresponding depths using 51 PVC Niskin water bottles equipped with silicon tubing to minimize rubber toxicity (Price et al. 1986). Deeper samples were collected if the chl a maximum was below the $1 \%$ light depth. Samples were shielded from direct sunlight and transferred to 10 I Nalgene ${ }^{8}$ carboys and immediately taken into the ship's laboratory. Subsamples for nutrient analyses were removed with an acid-washed syringe and gently filtered through combusted $\left(460^{\circ} \mathrm{C}\right.$ for $\left.4 \mathrm{~h}\right)$ Whatman ${ }^{\circledast} \mathrm{GF} / \mathrm{F}$ filters into acidwashed polyethylene bottles. Dissolved nitrate (plus nitrite), and ammonium were analyzed immediately on board ship and samples for urea were stored frozen on board ship and analyzed ashore.

Nutrient analysis. All nutrients were determined using a Technicon AutoAnalyzer ${ }^{\oplus}$ II. Salinity effects on nutrient analysis were tested on board ship and were found to be small. Therefore, no corrections were made for salinity effects.

Nitrate (plus nitrite) and ammonium were determined following the procedures of Wood et al. (1967) and Slawyk \& Maclsaac (1972), respectively. Urea was determined by the diacetyl monoxime thiosemicarbizide technique described by Price \& Harrison (1987), with the following modifications: (1) the temperature of the oil bath was kept at $90^{\circ} \mathrm{C}$, and (2) the waste tube returned to the pump, thus forming a completely enclosed system.

${ }^{14} \mathrm{C}$ uptake, chl a, particulate organic carbon and nitrogen. $\mathrm{NaH}^{14} \mathrm{CO}_{3}$ preparation, the ${ }^{14} \mathrm{C}$ uptake experimental procedure, and the calculation of primary productivity per $\mathrm{m}^{2}$ are described in Harrison et al. (1991). Samples for chl a were filtered onto Whatman GF/F filters. Filters were placed into $10 \mathrm{ml}$ of $90 \%$ acetone and sonicated (in the dark) for $10 \mathrm{~min}$ in ice-cold water. After sonication, chl a was extracted in the cold and dark for $24 \mathrm{~h}$ in $90 \%$ acetone, and analyzed by in vitro fluorometry (Parsons et al. 1984) using a Turner Designs ${ }^{\circledast}$ model 10 fluorometer. Samples for particulate organic carbon and nitrogen (POC and PON, generally $500 \mathrm{ml}$ ) were collected on combusted $\left(460^{\circ} \mathrm{C}\right.$ for $4 \mathrm{~h}$ ) Whatman $\mathrm{GF} / \mathrm{F}$ filters and stored frozen in a desiccator. After the cruise, the filters were dried for $24 \mathrm{~h}$ at $-60^{\circ} \mathrm{C}$ and analyzed with a Carlo Erba model NA 1500 NCS elemental analyzer, using the dry combustion method described by Sharp (1974).

Zooplankton. Zooplankton samples were obtained using a closing WP2 net (303 $\mu \mathrm{m}$ mesh, $57 \mathrm{~cm}$ diameter) hauled vertically at ca $1 \mathrm{~m} \mathrm{~s}^{-1}$. Filtering efficiency of the nets was determined using a calibrated flow meter, which was removed during sampling in order to minimize the pressure wave in front of the net. Triplicate vertical hauls were made from $25 \mathrm{~m}$ to the sur- face. Samples were preserved in $5 \%$ borax-buffered formalin for later identification and enumeration.

Winds, tides and river discharge. Observed hourly tidal heights were provided by the Tides and Current Section, Institute of Ocean Sciences, Sidney, B.C., Canada. The discharge data for the Fraser River at Hope were obtained from the Water Survey of Canada. The wind data were recorded at the Vancouver International Airport and provided by Atmospheric Environment Service, Environment Canada.

\section{RESULTS}

\section{Winds, tides and river discharge}

The river discharge started to increase gradually from April $2\left(1000 \mathrm{~m}^{3} \mathrm{~s}^{-1}\right)$ to April $14\left(1500 \mathrm{~m}^{3} \mathrm{~s}^{-1}\right)$ and then rapidly climbed to $2750 \mathrm{~m}^{3} \mathrm{~s}^{-1}$ on April 19, indicating the beginning of the spring freshet of 1991 (Fig. 2A, B). A wind event occurred during April 3-10, with speeds $>6 \mathrm{~m} \mathrm{~s}^{-1}$ on April 3 which remained above $4 \mathrm{~m} \mathrm{~s}^{-1}$ until April 10 (except for April 7) (Fig. 2C). Wind direction was mainly from the south and east during April 3-9 and shifted to mostly westerly during April 15-18. There was a neap tide on April 11 and spring tides on April 2 and 17 (Yin 1994).

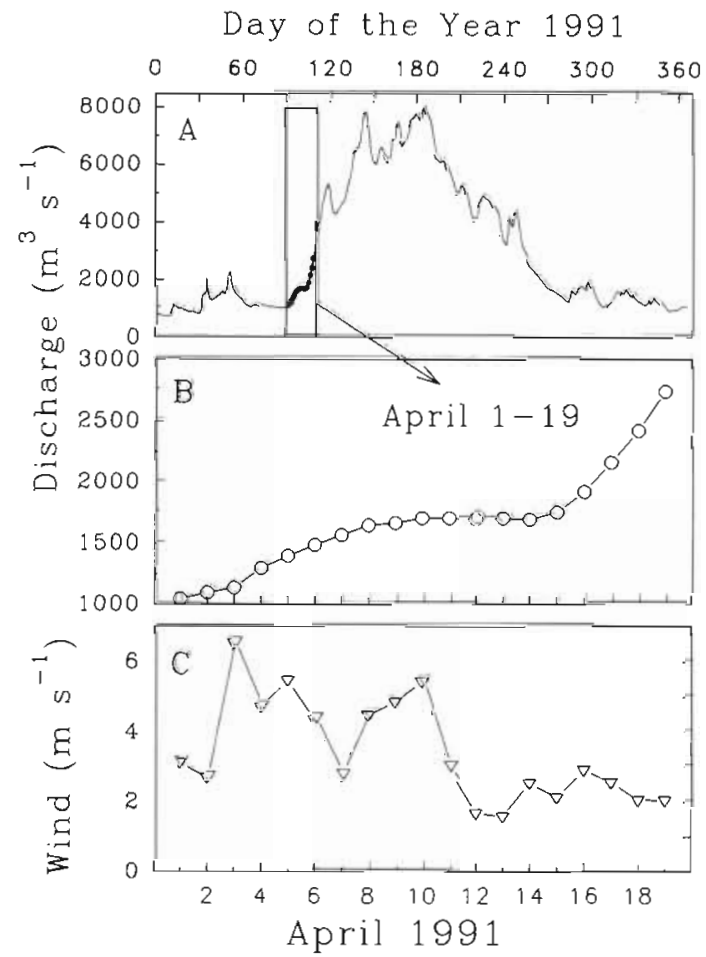

Fig. 2. (A) Fraser River discharge for 1991 at Hope. (B) Fraser River discharge and (C) daily averaged wind speed during April 1-19, 1991 


\section{Areal phytoplankton biomass and production}

Chl a concentrations and primary production reached ca $80 \mathrm{mg}$ chl a m $\mathrm{m}^{-2}$ and $3900 \mathrm{mg} \mathrm{C} \mathrm{m}^{-2} \mathrm{~d}^{-1}$ at Stn S3 on April 4-5 (Fig. 3). Chl a concentrations and primary production dramatically decreased almost by half during April 7-10 (note the different scale in Fig. 3) except for primary production at Stn S2 as the winds continued to blow. Five days later on April 15, they were even lower (Fig. 3), suggesting a continuing decrease after the winds had relaxed (ca $2 \mathrm{~m} \mathrm{~s}^{-1}$ ) on April 11. During April 15-18, chl a and primary production increased gradually, but the magnitude did not reach the values at the beginning of the wind event. Both chl a concentrations and primary production were highest at Stn S3 on April 4-5 and higher near the river mouth (Stns S2 and S3) than at the seaward station (Stn S1) during April 7-10. After the wind event, the region of maximal chl $a$ and primary production moved to Stn P3, further seaward of the river mouth. These changes were attributed to changes in the hydrodynamics of the water column, as described below.

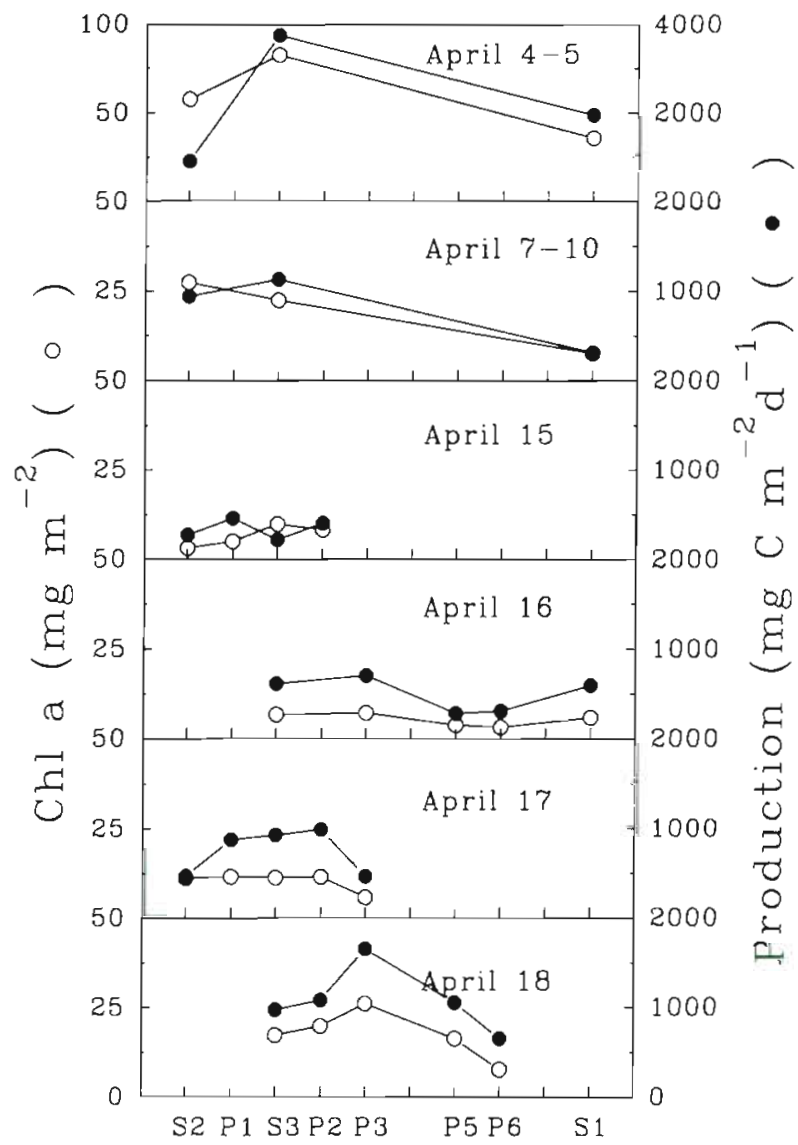

Fig. 3. Temporal and spatial changes in chl a $\left(\mathrm{mg} \mathrm{m}^{-2}\right)$ and primary production ( $\mathrm{mg} \mathrm{C} \mathrm{m} \mathrm{C}^{-2} \mathrm{~d}^{-1}$ ) along the transect from Stns S2 to S1 during April 4-18, 1991. Note that the $y$-axis scale for April 4-5 differs from those of the other periods

\section{Salinity}

At the beginning of the wind event, on April 4-5, the water column at Stns S3, P2 and P4 was still stratified (Fig. 4). Near the end of the wind event on April 8-9 vertical mixing was evident. For example, at Stn S3, the water column in the upper $22 \mathrm{~m}$ was almost completely mixed and the surface salinity increased from 27.5 to $>29$ (Fig. 4). At Stn P4, the salinity in the upper layer of the water column (top $7 \mathrm{~m}$ ) also increased by 1.5 between April 4 and April 8 (Fig. 4).

On April 15, the surface salinity decreased and was comparable to the salinity at the beginning of the wind event (Fig. 4). If a difference in salinity between the surface and the bottom $(20 \mathrm{~m})$ of a vertical profile is used to indicate the strength of the stratification of the water column, it is clear that the water column had been stratified during April. 15-18 and that the stratification was stronger near the river mouth. Note that the halocline was gradual and occupied most of the upper $20 \mathrm{~m}$ layer at all the stations (Fig. 4). This indicates that the outflowing freshwater could not remain as a distinct water mass due to continuous vertical mixing by tides and winds as it moved away from the river mouth. The spatial and temporal distribution of nutrients reflected these hydrodynamic changes.

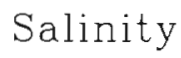

$\begin{array}{lllllllllllll}26 & 27 & 28 & 29 & 30 & 27 & 28 & 29 & 30 & 27 & 28 & 28 & 30\end{array}$

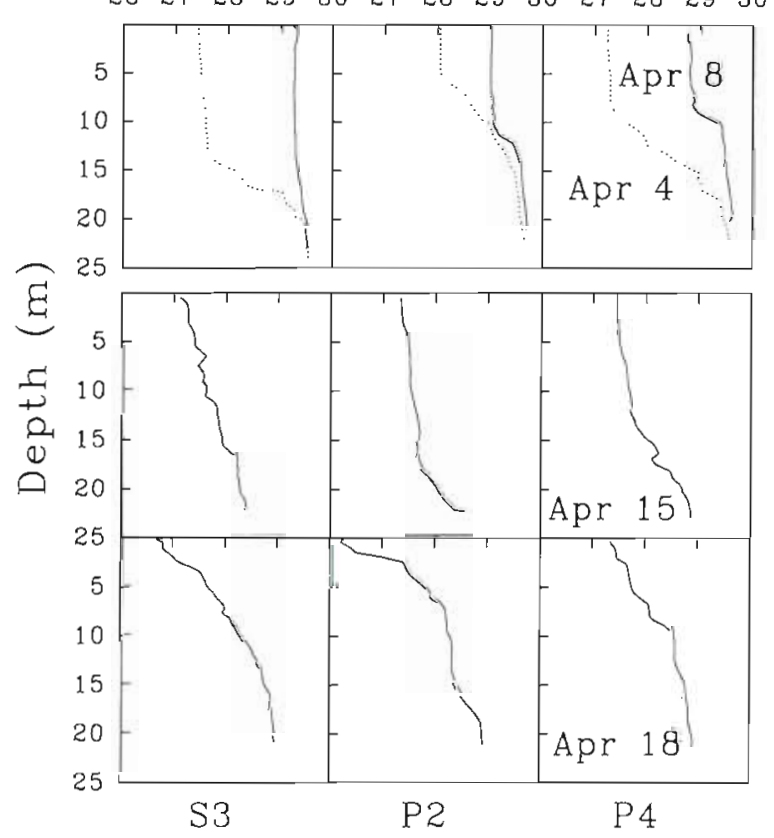

Fig. 4. Vertical profiles of salinity at Stns S3, P2 and P4 along the transect for April 4 (dotted line; beginning of the wind event), April 8 (solid line; end of the wind event), April 15 and 18,1991 


\section{Nutrients}

$\mathrm{NO}_{3}$

On April 4, the surface $\mathrm{NO}_{3}$ concentrations were between 6 and $11 \mu \mathrm{M}$ at Stns S3, P2 and P4 and the nutricline was deeper near the river mouth than seaward (Fig. 5). By April 8, the surface $\mathrm{NO}_{3}$ concentrations increased by about $10 \mu \mathrm{M}$ at the surface at all the stations (Fig. 5). Seven days after the wind event (April 15), $\mathrm{NO}_{3}$ concentrations were lower than they had been on April 8 (Fig. 5). The vertical gradients of $\mathrm{NO}_{3}$ concentration were gradual. The differences in the surface $\mathrm{NO}_{3}$ concentrations at Stns S3, P2, and P4 between April 8 and 15 were $7-13 \mu \mathrm{M}$. $\mathrm{NO}_{3}$ concentrations in the water column decreased slowly (Stns S3, P2 and P4) over the next $3 \mathrm{~d}$, April 15-18 (Fig. 5).

$\mathrm{NH}_{4}$

$\mathrm{NH}_{4}$ concentrations were around $0.5 \mu \mathrm{M}$ during April 4 and 8 and increased to 1.3 to $2 \mu \mathrm{M}$ during April 15-18 (Fig. 6).

\section{Total nitrogen}

Total nitrogen (TN) was above $20 \mu \mathrm{M}$ at the surface at all the stations and as high as $32 \mu \mathrm{M}$ at depth during

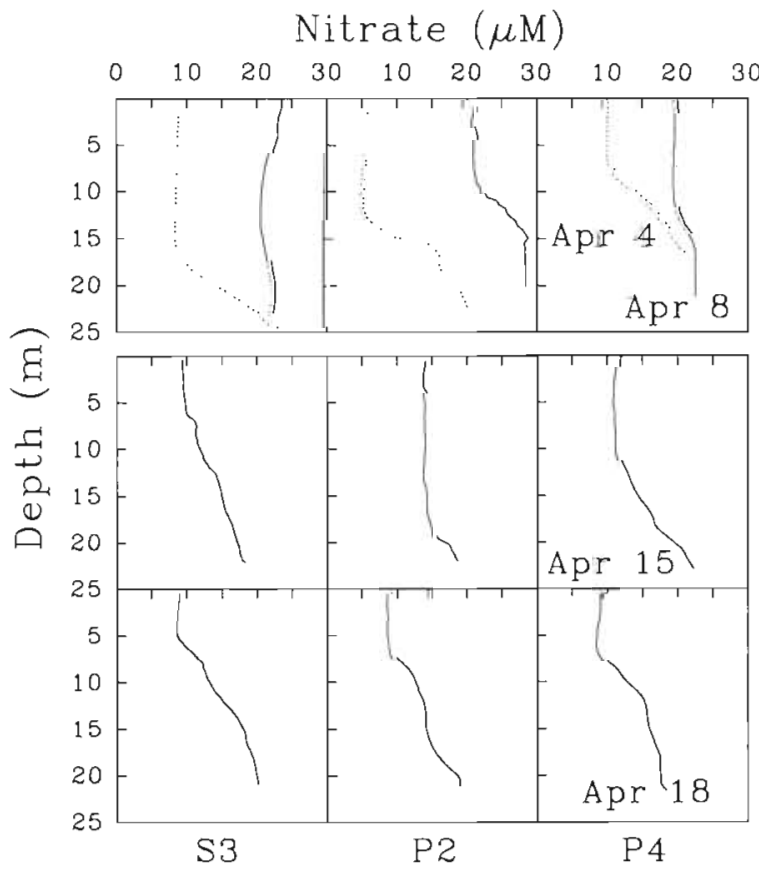

Fig. 5. Vertical profiles of $\mathrm{NO}_{3}$ at Stns S3, $\mathrm{P} 2$ and $\mathrm{P} 4$ along the transect for April 4 (dotted line), April 8 (solid line), April 15 and April 18, 1991

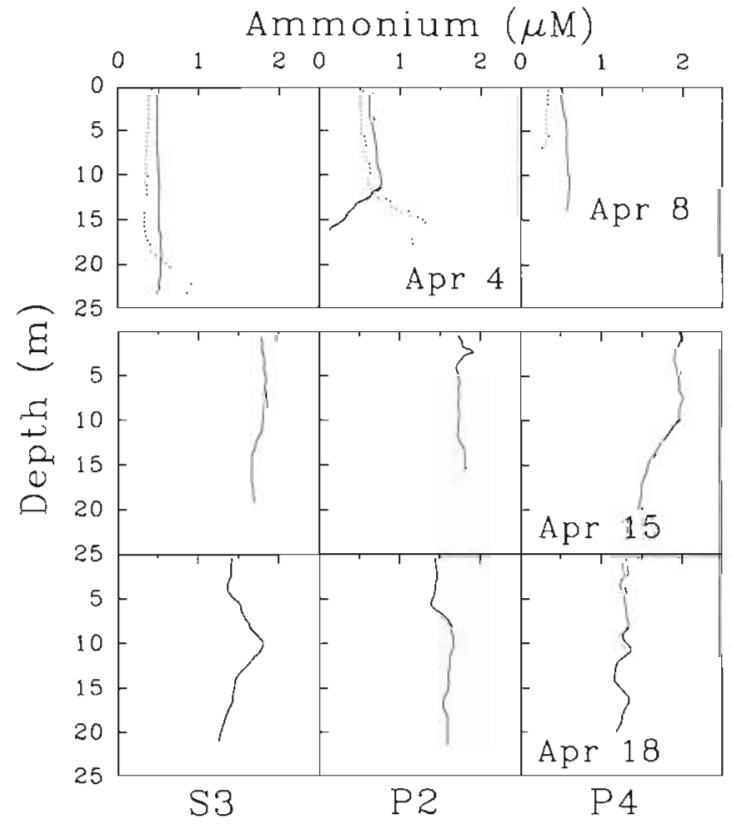

Fig. 6. Vertical profiles of $\mathrm{NH}_{4}$ at Stns $\mathrm{S} 3, \mathrm{P} 2$ and $\mathrm{P} 4$ along the transect for April 4 (dotted line), April 8 (solid line), April 15 and 18,1991

the wind event (Fig. 7). The maximum vertical difference in TN was about $7 \mu \mathrm{M}$. Particulate nitrogen data were not collected after the wind event. However, particulate nitrogen was significantly $(\mathrm{p}<0.005)$ related to chl a during April 4-9 (Fig. 8). The equation derived from the regression was used to calculate PON from chl a during April 15-18. TN was reduced at the surface (to as low as $16 \mu \mathrm{M}$ ) and the deeper depths ( $<28 \mu \mathrm{M}$ at most stations) after the wind event (Fig. 7), Also, the vertical differences in TN between the surface and the lower layer $(20 \mathrm{~m})$ were increased.

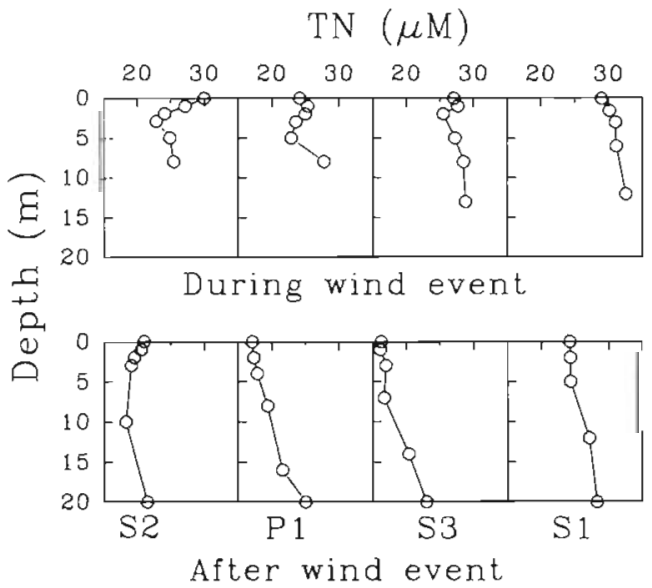

Fig. 7. Vertical profiles of total nitrogen (TN) during the wind event (April 4-9) and after the wind event (April 15-19), 1991, at some stations along the transect 


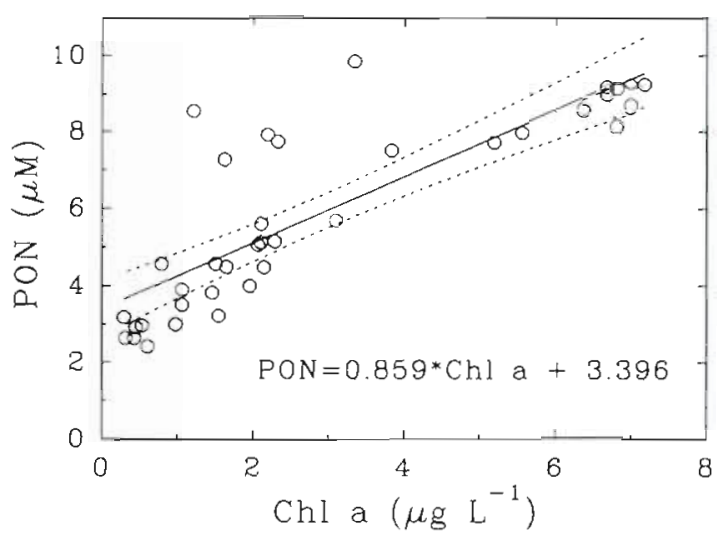

Fig. 8. Regression of particulate organic nitrogen (PON) over chl a during April 4-9, 1991 The regression equation is shown $\left(\mathrm{r}^{2}=0.835, \mathrm{p}<0.005\right)$. Dotted lines are $95 \%$ confidence intervals

\section{Zooplankton}

The copepods Neocalanus plumchrus and Pseudocalanus spp. were the most abundant zooplankton in the top $25 \mathrm{~m}$ of the water column during the cruise

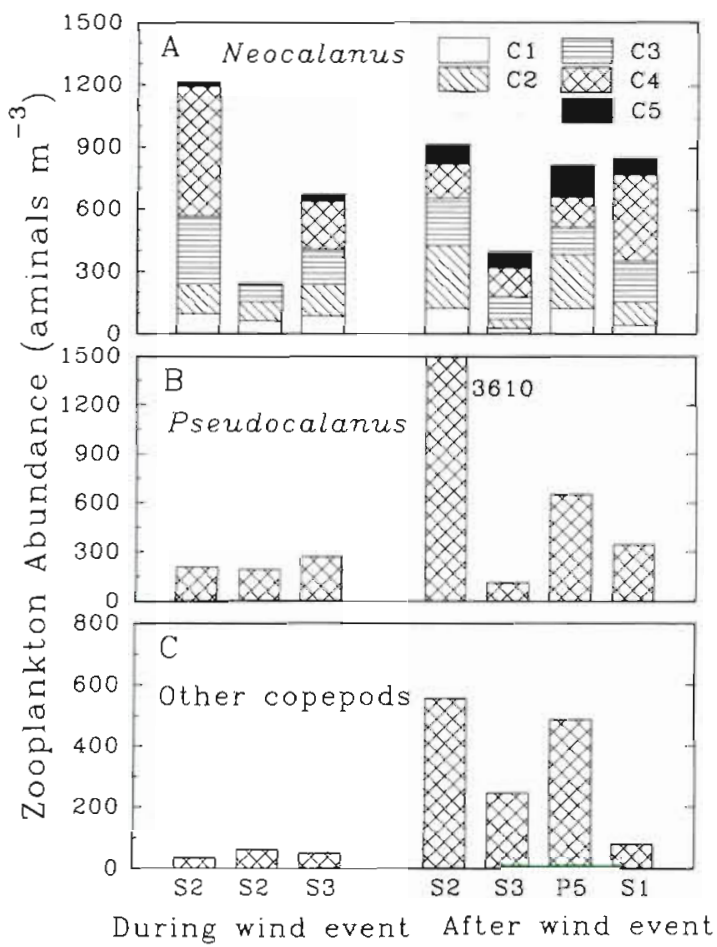

Fig. 9. Zooplankton abundance in the top $25 \mathrm{~m}$ at some stations along the transect during the wind event (April 3-10) and after the wind event (April 15-18). (A) Neocalanus plum. chrus, showing the proportion of copepodite stages $\mathrm{C} 1$ through C5, (B) Pseudocalanus spp., and (C) other zooplankton uncluding Calanus sp., Acartia longiremis, Eucalanus sp. and Centropages sp.
(Fig. 9). At Stn S2, the number of $N$. plumchrus varied from 225 to $1225 \mathrm{~m}^{-3}$ during the wind event. Although the number did not appear to increase after the wind event, the number of later stage copepodites (stage V) did increase (Fig. 9). The abundance of Pseudocalanus spp. increased after the wind event. For example, at Stn S2 the number of Pseudocalanus spp. increased markedly from $<200$ to $>3600 \mathrm{~m}^{-3}$. The abundance of other copepods also increased after the wind event (Fig. 9)

\section{DISCUSSION}

\section{River discharge and winds}

The water column stratification was well developed at Stns S3, P2, and P4 before the beginning of the wind event (Fig. 4), suggesting that the Fraser River discharge in March had been sufficient to counteract tidal and wind mixing. The freshwater-influenced region had not yet expanded into the entire central Strait of Georgia (Yin 1994). The stability of the water column allowed phytoplankton to bloom since phytoplankton biomass and production were higher in the more stratified region. An average wind speed of about $5 \mathrm{~m} \mathrm{~s}^{-1}$ over $7 \mathrm{~d}$ destroyed the stratification, suggesting the water column must have been vulnerable to wind mixing during the establishment of stratification in spring. A decrease in stratification from March to April had previously been shown for this region (Crean \& Ages 1971, see their Figs, 14 \& 18), possibly due to strong winds. After the wind event, the stratification was quickly re-established at the start of the annual freshet.

Because of the stratification and high nutrient concentrations in the surface layer, the spring bloom in 1991 was underway in late March and early April and its magnitude was greater near the river mouth. These results agree with earlier work by Parsons et al. (1969) This spatial pattern in the spring bloom in our study certainly resulted from the freshwater influence of river discharge and could not be attributed to thermal stratification because vertical profiles of temperature along the same transect displayed little stratification during April 2-9 (Yin 1994).

\section{Slow recovery of the spring bloom}

Low concentrations of chl a and low phytoplankton production on April 15 compared to April 7-8 indicated a slow recovery of the spring bloom after the wind event. This notion was supported by the distribution in $\mathrm{NO}_{3}$ concentration. Lower $\mathrm{NO}_{3}$ concentrations 


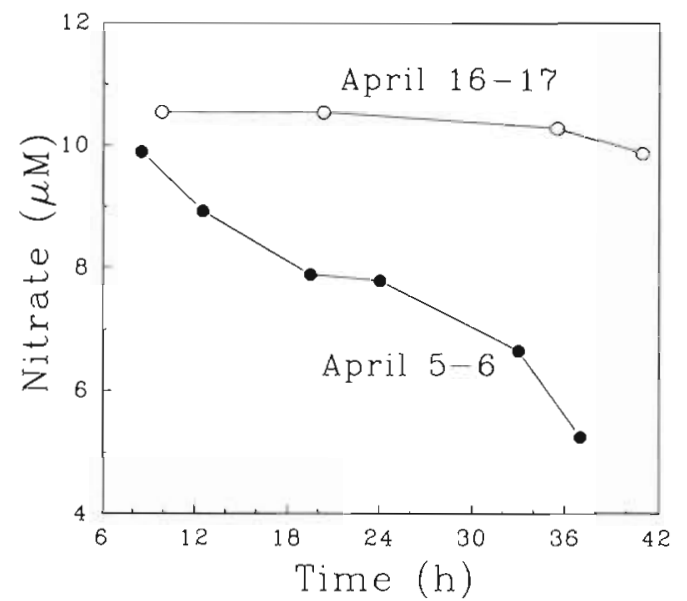

Fig. 10. Changes in $\mathrm{NO}_{3}$ concentrations over 30 h during the incubation experiments of $20 \mathrm{l}$ carboy seawater under in situ light conditions for surface samples taken at Stn S3 on April 5 and April 16

on April 15 than on April 8 indicated $\mathrm{NO}_{3}$ consumption between April 8 and April 15. However, the consumed $\mathrm{NO}_{3}$ did not show up as chl a in the water column on April 15. The rate of decrease in surface $\mathrm{NO}_{3}$ concentrations was less than $1 \mu \mathrm{M}$ per day at Stn S3 and P4 over 3 d, April 15-18 (Fig. 5). The slow decrease was consistent with the incubation experiments of a surface sample from Stn S3 on April 16 which showed little decrease in $\mathrm{NO}_{3}$ concentration over $30 \mathrm{~h}$ (Fig. 10). In contrast, the sample from the same station on April 5 incubated over the same period showed a decrease of $4.5 \mu \mathrm{M} \mathrm{NO}_{3}$ (Fig. 10), which was comparable to the rates reported by Antia et al. (1963) and Spies \& Parsons (1985), who showed that $\mathrm{NO}_{3}$ concentrations decreased by $>4.5 \mu \mathrm{M}$ per day during the log phase of the incubation of seawater in microcosms.

These observations indicated that the spring bloom did not resume rapidly after the wind event when the water column was stable and nutrients were abundant. The mechanism for this is an increase in grazing pressure by mesozooplankton after the wind event.

\section{Grazing}

The total abundance of copepods in the upper water column remained the same or slightly higher after the wind event as compared to before. However, the number of later stage (copepodite V) Neocalanus plumchrus, the dominant copepod, increased. Dagg (1993) has shown that the ingestion rate of $N$. plumchrus approximately doubles with each successive stage in its life cycle in the open ocean. A similar increase in ingestion rate is expected for this species in the Strait of Georgia, which indicates that grazing pressure increased after the wind event. The contribution to grazing of the other abundant copepod, Pseudocalanus spp., could also be substantial due to its increased abundance after the wind event. As a result of higher community grazing rates on a reduced phytoplankton biomass after the wind event, the recovery of the spring bloom was slowed down. The changes in concentrations of $\mathrm{NH}_{4}$ and $\mathrm{TN}$ were indicative of this grazing impact as well.

\section{$\mathrm{NH}_{4}$ concentrations}

There were higher $\mathrm{NH}_{4}$ concentrations on April 15-18 than on April 4-8 (Fig. 6). The main sources for $\mathrm{NH}_{4}$ in the euphotic zone in the Strait of Georgia estuary are the Fraser River discharge, the deeper water below the euphotic zone and biological regeneration including bacterial activity and zooplankton excretion. $\mathrm{NH}_{4}$ in the Fraser River was about $5 \mu \mathrm{M}$ during this period. This concentration was not high enough to maintain the 1.3-2 $\mu \mathrm{M}$ observed in the water column after the freshwater had been mixed with seawater in which $\mathrm{NH}_{4}$ concentrations were low (ca $0.5 \mu \mathrm{M}$, Fig. 6) on April 8. The $\mathrm{NH}_{4}$ concentrations at $20 \mathrm{~m}$ at Stn S3 at the end of the wind event was $0.5 \mu \mathrm{M}$ and therefore, the deep seawater could not contribute to higher $\mathrm{NH}_{4}$ concentrations during April 15-18. Bacterial activity was not measured during this cruise, but it is not important in this region when salinity exceeds 20 (Albright 1983, Harrison et al. 1991). Therefore, the increase in $\mathrm{NH}_{4}$ concentrations after the wind event must have come mainly from zooplankton excretion, and the higher remaining $\mathrm{NH}_{4}$ concentrations during April 15-19 indicated that $\mathrm{NH}_{4}$ generated by zooplankton exceeded phytoplankton utilization.

\section{Total nitrogen}

More evidence to demonstrate the impact of grazing on phytoplankton biomass is the mass balance of $\mathrm{TN}$ including dissolved inorganic (DIN: $\mathrm{NO}_{3}+\mathrm{NO}_{2}$, $\mathrm{NH}_{4}$, and urea) and particulate organic (PON) nitrogen. When DIN starts to decrease due to phytoplankton utilization, PON of phytoplankton will increase by the same amount. Therefore, TN will remain unchanged unless there are losses of phytoplankton out of the defined layer by grazing or sedimentation. In this mass balance, dissolved organic nitrogen (DON) is not included. As long as DON is not substantially different between depths, this approach is valid. A temporal difference in integrated TN over a layer of the water column between April 8 and April 15 can be viewed as a loss of TN during this period. Also, a ver- 
tical difference in $T N$ between the surface and the lower layer indicates a loss of TN out of this layer of the water column. The larger the difference is, the greater the loss. During the wind event, the vertical differences in TN were small (Fig. 7), indicating the small loss of TN to zooplankton. After the wind event, reduced TN concentrations over the water column compared to during the wind event and the larger differences between the surface and the depth $(20 \mathrm{~m})$ indicate the larger loss of TN out of the euphotic zone between the wind event and April 15-18. This loss certainly resulted from higher grazing after the wind event as suggested by zooplankton abundances during April 15-18.

\section{Significance of the wind event}

The wind event interrupted the development of the spring bloom. When the bloom started to recover, large numbers of copepods had migrated to the surface layer. Thus, the phytoplankton biomass was reduced by heavy zooplankton grazing, $\mathrm{NO}_{3}$ utilization slowed and $\mathrm{NH}_{4}$ excretion by zooplankton exceeded its uptake by phytoplankton. The consequence was that the phasing between phytoplankton and zooplankton in the Strait of Georgia was altered. Mediation of algal growth by nutrients and zooplankton was observed in studies by Elser et al. (1987) and Lampert et al. (1986). Wind events have also been reported to affect food chain dynamics within the New York Bight, where the interaction between storms and stratification affects the structure and frequency of chl a distributions across the shelf, which might influence both the survival strategies of herbivores and the loci of energy transfer to the rest of the food chain (Walsh et al. 1978). It is possible that juvenile salmon survival and growth could be related to these trophodynamic changes as consequences of wind events.

Therefore, wind and zooplankton grazing are important interacting factors that govern the magnitude and rate of development of the spring bloom in the Strait of Georgia estuary. Our next study will examine the interannual variability of the interacting effects of wind events and zooplankton grazing on the spring bloom.

Acknowledgements. We thank Dr Mike St. John who coordinated the cruises, Peter Clifford who conducted ${ }^{14} \mathrm{C}$ uptake experiments and other measurements and Heidi Nadene Sawyer for preparations for POC and PON analyses. Thanks are extended to the Department of Fisheries and Oceans for providing ship time, and the officers and crew of C.S.S. Vector for their assistance. Comments by Drs Steve Pond and James Cloern as well as 3 anonymous reviewers were helpful.
This research was funded by a Natural Sciences and Engineering Research Council of Canada (NSERC) Strategic grant. The Research Fellowship to support Kedong Yin was kindly provided by the Department of Fisheries and Oceans, Pacific Biological Station, Nanaimo, B.C., Canada.

\section{LITERATURE CITED}

Albright LJ (1983) Heterotrophic bacterial biomass, activities, and productivities within the Fraser River plume. Can J Fish Aquat Sci 40 (Suppl 1):216-220

Antia NJ, McAllister CD, Parsons TR, Stephens K, Strickland DH (1963) Further measurements of primary production using a large volume plastic sphere. Limnol Oceanogr 8 : $166-183$

Crean PB, Ages AB (1971) Oceanographic records from twelve cruises in the Strait of Georgia and Juan de Fuca Strait, 1968. Department of Energy, Mines and Resources, Marine Research Sciences Branch, Victoria, BC, Vols $1-5$

Dagg M (1993) Grazing by the copepod community does not control phytoplankton production in the subarctic Pacific Ocean. Prog Oceanogr 32:163-183

Elser JJ, Goff NC, MacKay NA, St. Amand AL, Elser MM, Carpenter SR (1987) Species-specific algal responses to zooplankton: experimental and field observations in three nutrient-limited lakes. J Plankton Res 9:699-717

Erga SR, Heimdal BR (1984) Ecological studies on the phytoplankton of Korsfjorden, western Norway. The dynamics of a spring bloom seen in relation to hydrographical conditions and light regime. $J$ Plankton Res 6:67-90

Frost BW (1980) Grazing. In: Morris I (ed) The physiological ecology of phytoplankton. Blackwell, Oxford, p 465-491

Fulton JD (1973) Some aspects of the life history of Calanus plumchrus in the Strait of Georgia. J Fish Res Bd Can 30: $811-815$

Harrison PJ, Clifford PJ, Cochlan WP, Yin K, St. John MA Thompson PA, Sibbald MJ, Albright LJ (1991) Nutrient and phytoplankton dynamics in the Fraser River plume, Strait of Georgia, British Columbia. Mar Ecol Prog Ser 70 291-304

Harrison PJ, Fulton JD, Taylor FJR, Parsons TR (1983) Review of the biological oceanography of the Strait of Georgia: pelagic environment. Can J Fish Aquat Sci 40 : $1064-1094$

Jones DM, Harrison PJ, Clifford PJ, Yin $K$. St. John MA (1991) A computer-based system for the acquisition and display of continuous vertical profiles of temperature, salinity, fluorescence and nutrients. Water Res 25 : $1545-1548$

Lampert W, Fleckner W, Rai H, Taylor BE (1986) Phytoplankton control by grazing zooplankton: a study on spring clear-water phase. Limnol Oceanogr 31:478-490

LeBlond PH (1983) The Strait of Georgia: functional anatomy of a coastal sea. Can J Fish Aquat Sci 40:1033-1063

Mann KH (1993) Physical oceanography, food chains, and fish stocks: a review. ICES J Mar Sci 50:105-1.19

Parsons TR, LeBrasseur RJ, Barraclough WE (1970) Levels of production in the pelagic environment of the Strait of Georgia, British Columbia: a review. J Fish Res Bd Can 27: $1251-1264$

Parsons TR, Maita Y, Lalli CM (1984) A manual of chemical and biological methods for seawater analysis. Pergamon Press, Oxford

Parsons TR, Stephens K, LeBrasseur RJ (1969) Production studies in the Strait of Georgia. Part I. Primary production 
under the Fraser River plume, February to May, 1967. J Exp Mar Biol Ecol 3:27-38

Price NM, Harrison PJ (1987) Comparison of methods for the analysis of dissolved urea in seawater. Mar Biol 94 $307-317$

Price NM, Harrison PJ, Landry MR, Azam F, Hall KJF (1986) Toxic effects of latex and tygon tubing on marine phytoplankton, zooplankton and bacteria. Mar Ecol Prog Ser 34 $41-49$

Sharp JH (1974) Improved analysis for 'particulate organic carbon and nitrogen' from seawater. Limnol Oceanogr 19: 984-989

Slawyk G, MacIsaac JJ (1972) Comparison of two automated ammonium methods in a region of coastal upwelling. Deep Sea Res 19:521-524

Sournia A, Birrien JL, Douvillé JL, Klein B, Viollier M (1987) A daily study of the diatom spring bloom at Roscoff (France) in 1985. I. The spring bloom with the annual cycle. Estuar Coast Shelf Sci 25:355-367

This article was presented by Y. Collos (Senior Editorial Advisor), Montpellier, France
Spies A, Parsons TR (1985) Estuarine microplankton: an experimental approach in combination with field studies. J Exp Mar Biol Ecol 92:63-79

Stockner JG, Cliff DD, Shortreed KRS (1979) Phytoplankton ecology of the Strait of Georgia, British Columbia. J Fish Res Bd Can 36:657-666

Walsh JJ, Whiteledge TE, Barvenik FW (1978) Wind events and food chain dynamics within the New York Bight. Limnol Oceanogr 23:659-683

Winter KF, Banse K, Anderson GC (1975) The dynamics of phytoplankton blooms in Puget Sound, a fjord in the northwestern United States. Mar Biol 29:139-176

Wood ED, Armstrong FAJ, Richards FA (1967) Determination of nitrate in seawater by cadmium-copper reduction to nitrite. J Mar Biol Ass UK 47:23-31

Yin K (1994) Dynamics of nutrients and phytoplankton production in the Strait of Georgia estuary, British Columbia, Canada. PhD thesis, University of British Columbia, Vancouver

Manuscript first received: January 15, 1995

Revised version accepted: March 19, 1996 